\title{
PENGARUH METODE PEMBELAJARAN TUTOR SEBAYA TERHADAP HASIL BELAJAR SISWA PADA MATA PELAJARAN TEKNOLOGI MEKANIK DI SMK
}

\author{
Ridwan Ramadhan ${ }^{1}$, Agus Solehudin ${ }^{2}$, Sabri $^{3}$ \\ Universitas Pendidikan Indonesia \\ Jl. Dr. Setiabudhi No. 229 Bandung 40154 \\ ridwan_ramadhan_9c@yahoo.co.id
}

\begin{abstract}
ABSTRAK
Penelitian ini bertujuan untuk memperoleh data tentang perbedaan metode pembelajaran ceramah dengan metode pembelajaran tutor sebaya. Metode yang digunakan yaitu deskriptif korelasional. Sampel penelitian ini sebanyak 36 orang siswa SMK. Hasil penelitian menunjukkan bahwa ada perbedaan hasil belajar siswa antara penggunaan metode pembelajaran ceramah dan metode pembelajaran tutor sebaya. Penerapan metode tutor sebaya meningkatan hasil belajar siswa pada kategori kognitif sebesar $86,1 \%$. Metode pembelajaran tutor sebaya mempengaruhi hasil belajar siswa pada mata pelajaran Teknologi Mekanik sebesar 82,7\%. Disimpulkan bahwa penggunaan metode pembelajaran tutor sebaya memberikan pengaruh yang signifikan terhadap hasil belajar siswa pada mata pelajaran teknologi mekanik.
\end{abstract}

Kata kunci: tutor sebaya, hasil belajar, teknologi mekanik

\section{PENDAHULUAN}

Sekolah Menengah Kejuruan (SMK) merupakan lembaga pendidikan formal yang lulusannya dipersiapkan untuk memasuki dunia kerja. Siswa dituntut untuk menjadi seorang yang produktif, mampu bekerja mandiri, kualitas dalam berkarier, ulet, gigih dalam berkompetensi, dan bertanggung jawab dalam menjalankan tugas. Upaya untuk mempersiapkan peserta didik yang lulusannya diorientasikan untuk dunia kerja, maka penyelenggaraan proses pendidikan harus relevan dan mengarah pada tujuannya.

Program keahlian teknik pemesinan adalah program keahlian yang mempersiapkan lulusannya mampu mengoprasikan berbagai mesin produksi untuk menghasilkan sebuah produk. Untuk mencapai lulusan yang memiliki kompetensi tersebut, tentunya harus ditunjang dengan beberapa kompetensi salah satunya Mata pelajaran Teknologi Mekanik. Mata Pelajaran Teknologi Mekanik atau Pengerjaan Dasar Teknik Mesin (PDTM) merupakan mata pelajaran produktif dan salah satu mata pelajaran yang penting. Mata pelajaran ini menuntut siswa untuk

\footnotetext{
${ }^{1}$ Mahasiswa Departemen Pendidikan Teknik Mesin FPTK UPI

2 Dosen Departemen Pendidikan Teknik Mesin FPTK UPI

${ }^{3}$ Dosen Departemen Pendidikan Teknik Mesin FPTK UPI
} 
dapat menguasai dan mengimplementasikan beberapa gabungan pokok bahasan seperti memahami kesehatan keselamatan kerja dan lingkungan, penggunaan alat ukur, memahami penanganan material, memahami pengguanaan perkakas tangan, memahami pengoprasian mesin umum, memahami proses pengelasan, dan memahami proses pengecoran logam (Sudjana, 2005). Mata pelajaran Teknologi Mekanik disusun berdasarkan tuntutan paradigma pembelajaran pada kurikulum 2013 diselaraskan berdasarkan model pembelajaran yang sesuai dengan kebutuhan belajar dengan tujuan untuk peningkatan hasil belajar dan keterampilan siswa.

Model pembelajaran berfungsi sebagai pedoman dalam perancangan pembelajaran dan para guru merencanakan aktifitas pembelajaran. Perlu dipahami bahwa, salah satu bagian dari model pembelajaran adalah metode pembelajaran yang sesuai dengan mata pelajaran. Kasus yang dipilih pada penelitian ini difokuskan pada metode pembelajaran, dimana terdapat salah satu kekeliruan yang ditemui pada observasi awal dilapangan terdapat guru mata pelajaran Teknologi Mekanik masih menggunakan metode pembelajaran ceramah (Djaali, 2011). Hal ini cenderung berpengaruh pada hasil belajar peserta didik didalam kelas dengan contoh permasalahan, (1) siswa tidak mampu mempelajari dan sulit fokus pada materi yang sedang dijelaskan, dan (2) siswa merasa canggung bertanya ketika mengalami kesulitan dalam memahami materi yang sedang di bahas pada mata pelajaran tersebut. Hal ini dapat dipahami mata pelajaran Teknologi Mekanik membutuhkan metode pembelajaran yang mampu meningkatkan hasil belajar dalam ranah domain kognitif, domain afektif, domain psikomotor (Setyobudi, 2013).

Kekeliruan tersebut berdampak pada penurunan hasil belajar siswa. Jumlah siswa yang mendapatkan nilai dengan predikat baik 4,49 \%, predikat cukup 15,73\%, dan predikat kurang 79,78\%. Masih banyak siswa yang mendapat nilai yang tidak memenuhi Kriteria Ketuntasan Minimum (KKM). Keadaan tersebut menunjukkan adanya masalah yang dialami siswa untuk mencapai nilai sesuai dengan Kriteria Ketuntasan Minimum (KKM).

Evaluasi dari pihak SMK Negeri 6 Bandung khususnya Jurusan Teknik Pemesinan mengenai kurangnya sebagian nilai siswa yang belum memenuhi Kriteria Ketuntasan Minimum (KKM), dapat berpengaruh pada penyelesaian kompetensi selanjutnya. Apabila dianalisa lebih lanjut, dapat dikatakan salah satu aspek yang mempengaruhi siswa dalam menjalani proses pembelajaran mata pelajaran Teknologi Mekanik adalah faktor eksternal yaitu metode 
pembelajaran, solusi peneliti terhadap keberhasilan proses pembelajaran mencoba menerapkan metode pembelajaran tutor sebaya. Namun seberapa besar pengaruh metode pembelajaran tutor sebaya pada mata pelajaran teknologi mekanik masih menjadi pertanyaan sehingga patut ditelusuri dengan seksama (Prawira, 2012).

\section{METODE PENELITIAN}

Metode yang digunakan dalam penelitian ini adalah metode eksperimen dengan bentuk preexperimental design dengan bentuk one group pretest-posttest design. Dalam desain eksperimen ini tidak adanya variabel kontrol (kelas kontrol) dan tidak dipilih secara random. Dikatakan preexperimental design karena desain ini belum merupakan eksperimen sungguh-sungguh, karena masih terdapat variabel luar yang ikut berpengaruh terhadap terbentuknya variabel dependen. Penelitian mengandung paradigma bahwa terdapat suatu kelompok diberi treatment/perlakuan dan selanjutnya diobservasi hasilnya. Akan tetapi, sebelum diberi perlakuan terdapat pretest untuk mengetahui kondisi awal. Hasil perlakuan dapat lebih akurat karena dapat membandingkan dengan keadaan sebelum diberi perlakuan. Alur dari penelitian ini adalah kelas yang digunakan kelas penelitian (kelas eksperimen) diberi pre-test (O1) kemudian dilanjutkan dengan pemberian perlakuan/treatment (O2) yaitu penggunaan Metode Pembelajaran Tutor Sebaya setelah itu diberi post-test.

\section{HASIL PENELITIAN}

Hasil penelitian menunjukkan siswa yang mendapatkan nilai 10>20 berjumlah 8 orang, siswa yang mendapatkan nilai 21>30 berjumlah 10 orang, siswa yang mendapatkan nilai 31>40 berjumlah 11 orang, siswa yang mendapatkan nilai 41>50 berjumlah 5 orang, dan siswa yang mendapatkan nilai $51>60$ berjumlah 2 orang. Ketetapan sekolah mengenai nilai kriteria ketuntasan minimum (KKM) mata pelajaran Teknologi Mekanik adalah 75. Data nilai siswa tersebut menunjukkan siswa belum memenuhi KKM.

Hasil penelitian menunjukkan bahwa siswa yang mendapatkan nilai $61>70$ berjumlah 1 orang, siswa yang mendapatkan nilai 71>80 berjumlah 4 orang, siswa yang mendapatkan nilai $81>90$ berjumlah 24 orang, dan siswa yang mendapatkan nilai 91>100 berjumlah 7 orang. Data nilai siswa tersebut menunjukkan bahwa siswa yang belum memenuhi KKM berjumlah 1 orang memperoleh nilai 68,3 dan 2 orang memperoleh nilai 71. 
Uji regresi sederhana bertujuan untuk meramalkan keadaan data untuk dapat membantu dalam memecahkan suatu masalah. Konstanta sebesar 69,4, apabila nilai pretest (X) nilainya adalah nol. Hasil posttest variabel Y nilainya adalah 69,4. Koefisien regresi variabel dengan nilai 0,5 artinya koefisien arah regresi linier tersebut bertanda positif. Data tersebut dapat diprediksi setiap kenaikan hasil tes kompetensi teknik penggunaan alat ukur (X) adalah satu point, maka hasil post-test kompetensi teknik penggunaan alat ukur (Y) diprediksi akan meningkat sebesar 0,5 point

Analisis korelasi ini dilakukan untuk mengetahui bagaimana hubungan antara variabel kompetensi teknik teknik penggunaan alat ukur dengan variabel kompetensi teknik penggunaan alat ukur. Statistik yang digunakan koefisien korelasi pearson product-moment, karena data penelitian variabel X dan variabel Y berdistribusi normal. Hasil perhitungan koefisien korelasi dengan harga hitung r=0,9. Penafsiran kriteria korelasi, dapat diartikan bahwa derajat korelasi tersebut tergolong kategori korelasi sangat tinggi.

Besarnya kontribusi diperoleh nilai $r^{2}$ adalah 0,8. Artinya metode pembelajaran tutor sebaya mempengaruhi hasil belajar siswa pada mata pelajaran Teknologi Mekanik sebesar $82,7 \%$. Hipotesis yang diajukan. yaitu terdapat pengaruh yang signifikan antara metode pembelajaran tutor sebaya terhadap hasil belajar siswa pada mata pelajaran teknologi mekanik.

Hasil perhitungan pada uji gain ternormalisasi didapat nilai $\mathrm{g}=0,9$. Data tersebut termasuk pada kategori tinggi, dapat diartikan pengaruh yang dihasilkan dari penggunaan metode pembelajaran tutor sebaya sangat tinggi.

\section{PEMBAHASAN}

Berhasil atau tidaknya pencapaian tujuan pendidikan atau baik tidaknya prestasi siswa banyak bergantung kepada bagaimana proses belajar yang dialami oleh siswa. Sementara proses belajar mengajar sangat dipengaruhi oleh beberapa faktor agar tercapai prestasi belajar yang baik, faktor tersebut diantaranya adalah faktor eksternal. Pada pembelajaran konvensional, dimana bakat siswa tersebar secara normal. Mereka diberikan pembelajaran yang sama dalam jumlah pembelajaran dan waktu yang tersedia untuk belajar, sehingga hasil belajar yang dicapai akan tersebar secara normal pula (Dimyati dan Mudjiono, 2009).

Adanya standar penilaian belajar siswa yang di tentukan dalam KKM yang telah ditetapkan oleh pihak sekolah adalah 75, menuntut siswa untuk memperoleh nilai diatas kriteria 
ketuntasan minimum. Rata-rata nilai yang diperoleh siswa pada mata pelajaran teknologi mekanik dengan kompetensi Teknik Penggunaan Alat Ukur sebelum menggunakan metode tutor sebaya, nilai siswa masih di bawah standar kriter KKM. Hasil kompetensi teknik penggunaan alat ukur merupakan modal awal bagi siswa untuk dapat mempelajari mata pelajaran selanjutnya yang berhubungan dengan penggunaan alat ukur. Analisis data di atas menunjukkan, bahwa metode pembelajaran sangat menentukan hasil belajar siswa khususnya pada kategori kognitif (Widodo, 2013). Metode pembelajaran tutor sebaya cocok diterapkan pada siswa kelas X TPM. Tutor sebaya itu adalah yang pandai dapat memberikan bantuan belajar kepada siswa yang kurang pandai. Tutor sebaya adalah seorang atau beberapa orang siswa yang ditunjuk dan ditugaskan untuk membantu siswa yang mengalami kesulitan belajar. Tutor tersebut diambil dari kelompok yang prestasinya lebih tinggi (Izzati, 2015). Berdasarkan pendapat tersebut proses pembelajaran pada metode ini memiliki potensi pembelajaran di dalam kelas secara efektif dan efisien. Metode ini terciptanya pusat pembelajaran berada pada siswa (student center), sesuai dengan implementasi kurikulum 2013, dan berpengaruh pada peningkatan hasil belajar siswa.

Pengaruh metode pembelajaran tutor sebaya secara signifikan terhadap hasil belajar siswa pada mata pelajaran teknologi mekanik (Kusumah, et. al., 2018). Pengaruh tersebut ditunjukkan dengan adanya peningkatan hasil belajar pada kategori kognitif dengan nilai 84,9 pada persentase siswa sebesar 86,1\%, artinya kemampuan siswa dalam memperoleh nilai untuk kategori kognitif telah mampu melebihi nilai standar KKM. Berdasarkan hasil analisis tersebut dapat disimpulkan bahwa penggunaan metode pembelajaran tutor sebaya memberikan hasil belajar yang baik.

\section{KESIMPULAN}

Kesimpulan penelitian ini, sebagai berikut: penerapan metode pembelajaran tutor sebaya cocok untuk diterapkan pada Mata Pelajaran Teknologi Mekanik. Peningkatan nilai pada hasil belajar siswa dengan melebihi nilai minimum yang ditetapkan oleh pihak sekolah. Metode pembelajaran tutor sebaya berpengaruh secara signifikan terhadap hasil belajar siswa pada mata pelajaran Teknologi Mekanik ditunjukkan dengan nilai koefisien determinasi kategori tinggi. 


\section{REFERENSI}

Dimyati dan Mudjiono. (2009). Belajar dan Pembelajaran. Jakarta :PT Rineka Cipta.

Djaali. (2011). Psikologi Pendidikan. Jakarta: PT Bumi Aksara.

Izzati, N. (2015). Pengaruh Penerapan Program Remedial dan Pengayaan Melalui Pembelajaran Tutor Sebaya terhadap Hasil Belajar Matematika Siswa. EduMa, 4(1), 54-68.

Kusumah, M. I., Sutisna, Septian, D. (2018). Pengaruh Metode Pembelajaran Tutor Sebaya (Peer Teaching) terhadap Hasil Belajar Siswa Pada Mata Pelajaran Fisika Pokok Bahasan Vektor Kelas X MIPA MAN 1 Cirebon. Jurnal Pendidikan Fisika dan Sains, 1(1), 33-39.

Prawira, P. A. (2012). Psikologi Pendidikan dalam Perspektif Baru. Yogyakarta: Ar-Ruzz Media.

Setyobudi, A. (2013). Teknologi Mekanik. Malang: Kemendikbud.

Sudjana, N. (2005). Penilaian hasil proses belajar mengajar. Bandung: Remaja Rosdakarya.

Widodo, L. (2013). Peningkatan Aktivitas Belajar dan Hasil Belajar Siswa dengan Metode Problem Based Learning. Jurnal Fisika Indonesia, 49(17), 32-35. 